\title{
Torque Teno Virus (TTV) is Prevalent in Brazilian Non- human Primates and Chickens (Gallus gallus domesticus)
}

\author{
Torque Teno Virus (TTV) es Prevalente en Primates No Humanos \\ Brasileños y Pollos (Gallus gallus domesticus) \\ ${ }^{*, * *}$ Catroxo, M. H. B.; ${ }^{* * *}$ Nishiya, A.; ${ }^{* * *}$ Sabino, E.; ${ }^{* * * *}$ Teixeira, P. S.; \\ ${ }^{* * * * * *}$ Petrella, S.; ${ }^{* * * * * *}$ Milanelo, L.; ${ }^{* * * * * * *}$ Vieira, J.C.F. \& ${ }^{* *}$ Diaz, R. S.
}

CATROXO, M. H. B.; NISHIYA, A.; SABINO, E. ; TEIXEIRA, P. S.; PETRELLA, S.; MILANELO, L.; VIEIRA, J. C. F. \& DIAZ, R. S. Torque Teno Virus (TTV) is prevalent in Brazilian non-human primates and chickens (Gallus gallus domesticus). Int. J. Morphol., 26(2):363-372, 2008.

SUMMARY: Torque teno virus (TTV) is an infectious agent of worldwide distribution isolated by the first time as the agent of an acute post-transfusion hepatitis in a patient in Japan. It has been classified into a new floating genus called Anellovirus. Recent studies showed that TTV can also be identified in serum specimens obtained from domesticated farm animals and from non-human primates. To better understand the relationship between TTV and their hosts, a study to detect virus in the serum and whole blood of Brazilian non-human primates and in the plasm of chickens was performed by applying the PCR-UTR-A technique, followed by a genomic sequence and phylogenetic analysis. By nested-PCR-UTR, the DNA of TTV was detected in sera from 4 (5.3\%) of 75 Cebus apella, 2 (40\%) of 5 Alouata fusca, 1 (20\%) of 5 Alouata caraya, 1 (5.2\%) of 19 Callithrix penicilata, 1 (4\%) of 25 Callithrix jacchus, $1(20 \%)$ of 5 Saimiri sciureus and $1(25 \%)$ of 4 Leontopithecus chrysomelas. Phylogenetic analysis revealed that sequences detected in 8 samples clustered with TTV sequences So-TTV2 (Sagüinus oedipus) and At-TTV3 (Aotes Trivirgatus). Three sequences showed similarity with a human Torque Teno Minivirus (TLMV). TTV ORF2 DNA was detected in one sera sample and one whole blood sample of non-human primates and in one plasm sample of chicken. Phylogenetic analysis revealed that the sequences amplified by the ORF2 region show no difference between human, non-human primates and chicken. This is the first report of TTV in brazilian new world non-human primates and chicken.

KEY WORDS: Torque Teno Virus; Torque Teno Minivirus; Non-humans primates; Untranslated region; Nucleotide sequencing.

\section{INTRODUCTION}

Torque teno virus (TTV) is an infectious agent of worldwide distribution (Prescott \& Simmonds, 1998; Abe et $a l ., 1999)$, which was first isolated in Japan in the serum of a patient hospitalized with acute post-transfusion hepatitis of unknown etiology (Nishizawa et al., 1997; Okamoto et al., 1998 a, b). Since then it has been detected in non A-G hepatitis patients, being highly prevalent among individuals at risk for blood borne pathogens, such as haemophilics, hemodialysis patients, and intravenous drug users (Okamoto et al., 1998a).
TTV and Torque Teno Minivirus (TTMV) have been recently classified into a new floating genus called Anellovirus (Biagini et al., 2005).TTV is a non-enveloped, single-stranded, circular DNA virus with a genomic length of 3.4-3.9 kb (Nishizawa et al.; Miyata et al., 1999; Mushahwar et al., 1999). TTV associated particles with a diameter of $30-32 \mathrm{~nm}$ recovered from the sera of infected humans are observed as aggregates of various sizes on electron microscopy (Itoh et al., 2000).

\footnotetext{
Laboratory of Electron Microscopy, Institute Biological of São Paulo, Brazil.

** Laboratory of Retrovirology, Federal University of São Paulo-UNIFESP, Brazil.

*** Fundação Hemocentro de São Paulo, Brazil.

***** Institute of Biomedical Sciences, University of São Paulo, Brazil.

******** Institute Adolfo Lutz, São Paulo, Brazil.

${ }^{* * * * * * * *}$ Ecological Park of Tietê, São Paulo, Brazil.

******** Department of Surgical Techniques, Federal University of São Paulo-UNIFESP, Brazil.
} 
CATROXO, M. H. B.; NISHIYA, A.; SABINO, E. ; TEIXEIRA, P. S.; PETRELla, S.; MILANELO, L.; VIEIRA, J. C. F. \& DIAZ, R. S. Torque Teno Virus (TTV) is prevalent in Brazilian nonhuman primates and chickens (Gallus gallus domesticus). Int. J. Morphol., 26(2):363-372, 2008.

Transmission of this agent is caused not only by parenteral exposure but also by fecal exposure, which have been recently demonstred in a chimpanzee transmission study (Tawara et al., 2000). In addition, TTV has been detected in saliva, throat swabs, semen, tears, breast milk, hair skin (Saback et al., 1999; Goto et al., 2000; Inami et al., 2000; Osiowy \& Sauder, 2000), and raw or pasteurized milk (AlMoslih et al., 2007).

TVV DNA genome is divided into two regions: one extremely variable coding sequence, of $2.6 \mathrm{~kb}$, and one more conserved non-coding (UTR) of $1.2 \mathrm{~kb}$ which varies in length between $3808 \mathrm{nt}$ (SANBAN) and $3853 \mathrm{nt}$ (TA 278 and JA 20) (Erker et al., 1999; Hijikata et al., 1999). The coding region consists of 6 open reading frames (ORF1 to ORF6) (Yokoyama et al., 2002). The two major genes that codify the proteins are the ORF1 and ORF2 (Okamoto et al., 1999c; Miyata et al.). The non coding region is located between the end of ORF3 (Romeo et al., 2000). PCR with primers deduced from noncoding region (UTR) can detect TTV DNA of different genotypes (Okamoto et al., 1999c).

TTV isolates present highly divergent sequences, classified into 39 genotypes inserted into five major groups (1-5) (Peng et al., 2002; Devalle \& Niel, 2004). Studies recently pointed the existence of new members of the family TTV, the SANBAM, YONBAN, TTMV, SEN virus (SENV) and PM virus (PMV) considered new viral species based on the genomic divergences present in these strains (Cong et al., 2000; Hallett et al., 2000; Khudyakov et al., 2000; Takahashi et al., 2000; Diniz-Mendes et al., 2004).

Chimpanzees are susceptible to TTV infection (Mushahwar et al.) and one study of experimental transmission in these species showed that the animals can be cross infected by human species (Okamoto et al., 2000a,b). Species-specific TTV transmissions are reported in high frequencies among chimpanzees and other non-human primates (Leary et al., 1999; Verschoor et al., 1999; Abe et al., 2000; Cong et al.; Okamoto et al., 2000a,b; Noppornpanth et al., 2001; Thom et al., 2003; Barnet et al., 2004; Pujol et al., 2005) as well as between other domestic animals, such as dogs, cats, pigs, bovines, chickens, ovines, tupaias (thee shrews), wild boar (Sus scrofa) and camels (Leary et al.; Okamoto et al., 2001b; 2002; Martinez et al., 2006; Al-Moslih et al.). Recently high prevalence of TTV have been reported in swine herds in Canada, China, Korea, Spain, Thailand, USA, France, and in Brazil (Thom et al.; Barnet et al.; Mc Keown et al., 2004; Bigarré et al., 2005; Niel et al., 2005; Martelli et al., 2006).

To better understand the relationship between TTV and their hosts, we conducted a study to detect and characterize virus in Brazilian monkeys and domestic chickens (Gallus gallus domesticus).

\section{MATERIAL AND METHOD}

Animals: A total of 90 serum samples and 70 whole blood samples were obtained from non-human primates of both genders, including 25 Callithrix jacchus, 3 Callithrix kulii, 4 Leontopitecus crysomelas, 75 Cebus apella, 19 Callithrix penicilata, 2 Callithrix sp, 5 Alouata caraya, 5 Alouata fusca, 1 Saguinus m. niger, 1 Callithrix humeralifer, 3 Callithrix geoffroyi, 1 Aotus trivirgatus, 1 Calimico goeldi, 3 Saguinus m. midas, 1 Lagothrix lagotricha, 1 Erytrocebus pata, 2 Ateles b. marginatus, 1 Ateles peniscus, 4 Saimiri sciureus, 1 Saimiri fuscicollis, 1 Leontopitecus chrysopygus. These species are usually found in the Amazon Forest and Atlantic Rain Forest, in Brazil. These animals came from donnations or rescues and were apprehended and sent to several ecological and Zoological Parks in São Paulo, Brazil where they were maintained in captivity. The samples were collected from August 2000 to February 2001. Almost 117 samples of chicken plasm (Gallus gallus domesticus) of the following lineages: white, brown leghorn chickens and hens of yard, of both genders, from different poultry farms in the state of São Paulo, Brazil, were collected from May to September 2001. Samples were kept undisturbed at $-80^{\circ} \mathrm{C}$ freezer until testing.

Extraction of nucleic acids and amplification by PCR: Blood DNA was extracted using a DNA Extraction Kit (Qiagen) from $100 \mu \mathrm{l}$ whole blood. DNA was ressuspended in $100 \mu$ l buffer. Serum DNA $(50 \mu \mathrm{l})$ was mixed with $100 \mu \mathrm{l}$ Dnazol and $3 \mu \mathrm{l}$ Dextran T500 $(1 \mathrm{mg} / \mu \mathrm{l})$. The DNA was precipited with isopropanol and ressuspended in $25 \mu \mathrm{l}$ distilled water.

Nested UTR PCR: The first round of PCR was performed with primers NG133 (sense) and NG 147 (antisense) and the second round was carried out with primers NG 134 (sense) and NG 132 (antisense). PCR was carried out in 50 $\mu \mathrm{l}$ volume using $5 \mu \mathrm{l}$ of DNA, $10 \mathrm{pmol}$ of NG133 and NG 147 primers, $1.5 \mathrm{mM} \mathrm{MgCl} 2$ and $5 \mathrm{U}$ Taq polymerase. The PCR conditions were $94^{\circ} \mathrm{C} 30 \mathrm{~s}, 55^{\circ} \mathrm{C} 30 \mathrm{~s}, 72^{\circ} \mathrm{C} 30 \mathrm{~s}, 35$ cycles, with a final extension at $72^{\circ} \mathrm{C} 7 \mathrm{~min}$. The sequences of the primers utilized were NG 133 5'- GTA AGT GCA CTT CCG AAT GGC TGA G- 3' and NG 134 5'-AGT TTT CCA CGC CCG TCC GCA GC-3' and NG 132 5'-AGC CGG AAT TGC CCC TTG AC-3' and NG 147 5'-GCC AGT CCC GAG CCC GAA TTG CC-3' according to Okamoto et al. (1998a). 
Five $\mu l$ of the first PCR product and 10 pmoles $/ \mu$ of NG 134 and NG 132 primers were used for the second PCR under the same conditions. The amplification products of the first round of PCR were a $143 \mathrm{pb}$ fragment, and the product of the second round was a $110 \mathrm{bp}$ fragment. It was considered positive control for the TTV, a human serum from a TTV positive patient. Amplified products were separated by electrophoresis through a $2 \%$ agarose gel containing ethidium bromide, and visualized under UV light.

Sequencing. Sequence reactions were performed with the ABI Prism Big Dye Terminator Cycle sequencing Ready Reaction Kit (Applied Biosystems). Cycle sequencing was carried out with an automatic DNA Sequencer (ABI Prism 377 Sequencer - Applied Biosystem). The primers used were NG 134 and NG 132 of the UTR region. Sequence edition was performed using the Sequencher program 4.0.5 (Gene Code Corporation). Sequence alignments were generated by the Bioedit Program (Hall, 1999). The phylogenetic analysis were performed using Philip version 3.5 c (Felsentein, 1993).

Alignment with 14 edited sequences (11 from the UTR region and 3 from ORF-2 region) and series of standard sequences from different TTV genotypes from Gen Bank and from the literature (16 from UTR and 15 from ORF-2) were performed.

The sequence alignments were assessed using 1,000 bootstrap replicates using SEQBOOT Program (Felsentein, 1993). Phylogenetic trees were constructed by the neighbour- joining method (Saitou \& Nei, 1997). The consense tree was calculed using the Consense Program and visualized in the Treview Program version 1.6.6 (win 32) (Roderic, 2001). The genotypes of the TTV had been determined by comparing the lined sequences (GenBank accession numbers EU518620-EU518633).

\section{RESULTS}

Non humans Primates. 90 serum samples and 70 whole blood samples obtained from different species of the new world non human primates were analysed using the nested PCR of the UTR-A region.

Among these samples, 11 serum samples showed positive results. 2 aditional serum samples were positive by the amplification of the ORF-2 region. All DNAs from whole blood samples were negative.

Of these 11 samples, TTV UTR-A positive PCR detected in serum, 4 (5.3\%) out of 75 were from Cebus apella, 2 (40\%) of 5 were from Alouata fusca, 1 (20\%) of 5 from Alouata caraya, 1 (5.2\%) of 19 from Callithrix penicilata, 1 (4\%) of 25 from Callithrix jacchus, 1 (20\%) of 5 from Saimiri sciureus e $1(25 \%)$ of 4 from Leontopithecus chrysomelas. Regarding gender, 5 (45.5\%) were from female primates and $6(54.5 \%)$ from males. Among these animals 10 positive samples were from adults $(91 \%)$ and $1(9.0 \%)$ was from a younger animal.

Table I. Description of TTV positive samples by PCR of UTR-A and ORF-2 regions according to the species, gender, age and captivity origin. $\mathrm{M}=$ male, $\mathrm{F}=$ female, $\mathrm{A}=$ adults, $\mathrm{Y}=\mathrm{young}$.

\begin{tabular}{|c|c|c|c|c|c|}
\hline sample & Specie & Gender & Age & Origin & Positive PCR \\
\hline 07 & Cebus apella & $\mathrm{M}$ & $\mathrm{A}$ & Zoo Sorocaba, SP & UTR \\
\hline 13 & Callittrix penicilata & M & $\mathrm{A}$ & Zoo Sorocaba, SP & UTR \\
\hline 15 & Cebus apella & M & $\mathrm{A}$ & Zoo Sorocaba, SP & UTR \\
\hline 18 & Cebus apella & $\mathrm{F}$ & A & Parque Tietê, SP & ORF-2 \\
\hline 21 & Cebus apella & M & A & Zoo Campinas, SP & UTR \\
\hline 27 & Callithrix jacchus & $\mathrm{F}$ & A & Zoo Sorocaba, SP & UTR \\
\hline 32 & Callithrix jacchus & M & A & Zoo Sorocaba, SP & ORF-2 \\
\hline 65 & Alouatta caraya & $\mathrm{F}$ & $\mathrm{A}$ & Zoo Mogi-Mirim, SP & UTR \\
\hline 66 & Cebus apella & $\mathrm{F}$ & A & Zoo Guarulhos, SP & UTR \\
\hline 71 & Allouata fusca & $\mathrm{F}$ & $\mathrm{Y}$ & Zoo Taboão da Serra, SP & UTR \\
\hline 79 & Allouata fusca & $\mathrm{F}$ & A & Zoo São Paulo, SP & UTR \\
\hline 85 & Saimiri sciureus & M & A & Zoo São Paulo, SP & UTR \\
\hline 87 & Leontopithecus chrysomelas & M & A & Zoo São Paulo, SP & UTR \\
\hline 92 & Gallus g. domesticus & $\mathrm{F}$ & A & Itapevi, SP & ORF-2 \\
\hline
\end{tabular}




$\begin{array}{ll}\text { 1. TA278 } & 1 \\ \text { 2. JA1 } & 1 \\ \text { 3.T3PB } & 1 \\ \text { 11. TUS01 } & 1 \\ \text { 12. TJN01 } & 1 \\ \text { 13. SANBAN } & 1 \\ \text { Pt-TTV6 } & 1 \\ \text { Mf-TTV3 } & 1 \\ \text { Mf-TTV9 } & 1 \\ \text { TLMV-CBD231 } & 1 \\ \text { TLMV-CBD203 } & 1 \\ \text { TGP96 } & 1 \\ \text { So-TTV2 } & 1 \\ \text { At-TTV3 } & 1 \\ \text { Pt-TTV8-II } & 1 \\ \text { Ac-TTV65 } & 1 \\ \text { Af-TTV71 } & 1 \\ \text { Af-TTV79 } & 1 \\ \text { Ss-TTV85 } & 1 \\ \text { Ca-TTV21 } & 1 \\ \text { Lc-TTV87 } & 1 \\ \text { Ca-TTV13 } & 1 \\ \text { Ca-TTV07 } & 1 \\ \text { Cj-TTV27 } & 1 \\ \text { Gg-TTV15 } & 1 \\ \text { Ca-TTV66 } & 1 \\ \text { CAV/U65414 } & 1\end{array}$

1. TA2 78

2. JA1

3. T3 PB

11. TUSO1

12. TJN01

13. SANBAN

Pt-TTV6

Mf-TTV3

Mf-TTV9

TLMV-CBD2 314

TLMV-CBD2034

TGP96

So-TTV2

At-TTV3

Pt-TTV8-II

Ac-TTV 65

Af-TTV71

Af-TTV79

Ss-TTV85

Ca-TTV21

LC-TTV87

Ca-TTV13

Ca-TTV07

Cj-TTV27

Ca-TTV15

Ca-TTV6 6

$\mathrm{CAV} / \mathrm{U} 65414$

1. TA2 78

2. JA1

3. T3 PB

11. TUSO1

12. TJNO1

13. SANBAN

Pt-TTV6

Mf-TTV3

Mf-TTV9

TLMV - CBD2 3

TLMV - CBD2 03

TGP9 6

So-TTV2

At-TTV3

Pt-TTV8-II

Ac-TTV 65

Af-TTV71

Af-TTV79

Ss-TTV85
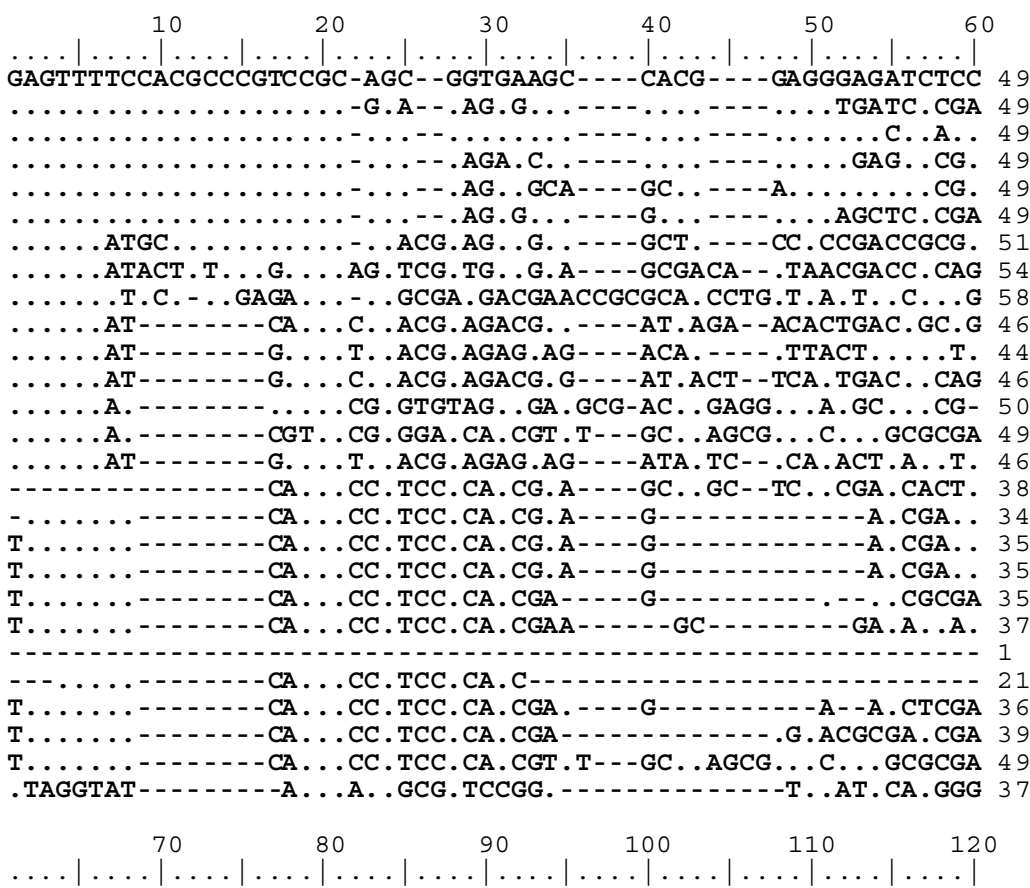

G-CGTCCCGAGGGCGGGTGCCGAAG- . - GTGAGTTTACACACCGAAGTCAAGGGGCA 102

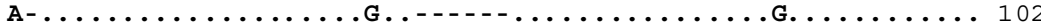

.$\ldots \ldots \ldots \ldots \ldots \ldots \ldots \ldots \ldots \ldots \ldots \ldots \ldots \ldots \ldots \ldots \ldots \ldots$

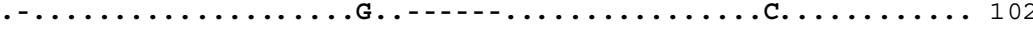

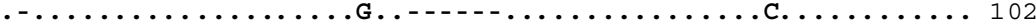

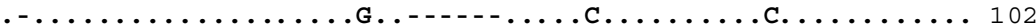

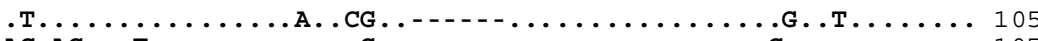

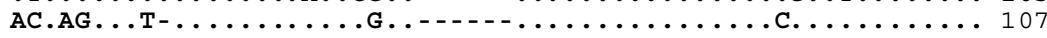

.C..C..GT-...........CG--.GAG.....C.C.GCG........ 113

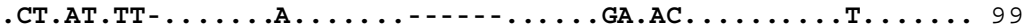

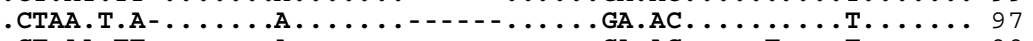

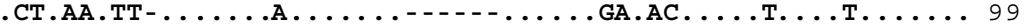

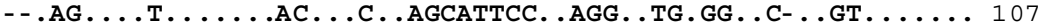

CCGAG.GACT . . . . . . . . GGAACA--TCC. .AGG. . TGTG- ... . . . . . 105

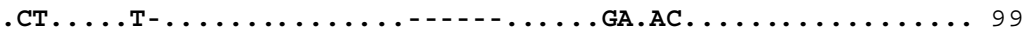

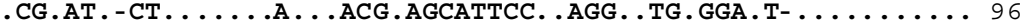

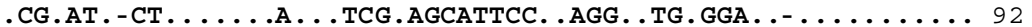

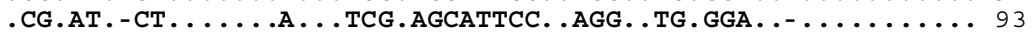

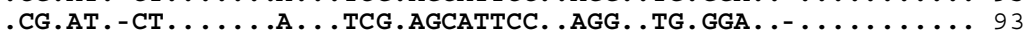

CCGAG.GACT . . . . . . . . CGAAGCATTCC. . AGG. . TG.GGA.C . . . . . . . 94

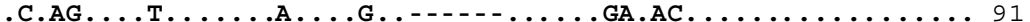

-- AG. . . . . . . . . . .

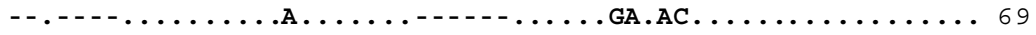

CCG.C.GACT. .......... . AACATTCC. . AGG. . TGTG-A.C- . . . . . 94

.G..A.T- . . . . . . . . . CG.AGCATTCC. GAGG. . TG.GGA.C- . . . . . . . 95

CCGAG.GACT . . . . . . . . GGAACA- TCC. . AGG. . TGTG- . . . . . . 105

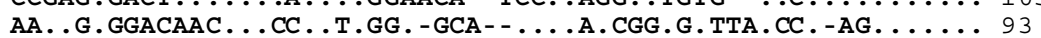

\section{ATTCGGGCT}

$103 \ldots \ldots . . . . .111$

$103 \ldots \ldots \ldots 111$

$103 \ldots \ldots \cdots \cdots+111$

$103 \ldots \ldots \ldots 111$

$103 \ldots \ldots \ldots 111$

$106 \ldots \ldots \ldots 114$

$108 \ldots \ldots \ldots$ A 116

$114 \ldots \ldots \ldots$ A 122

$100 \ldots \ldots \ldots 108$

$8 \ldots \ldots \cdots 106$

$100 \ldots \ldots \ldots 108$

$108 \ldots \ldots \ldots$ A 116

106 ATTCGGGCA 114

$100 \ldots \ldots$. . T 108

$97 \quad \ldots \ldots \ldots$ T 105

$93 \ldots \ldots \ldots-100$

$94 \quad \ldots \ldots$. 102

$94 \quad \ldots \ldots \ldots$ T 102
Fig. 1. Comparison between TTV-UTR-A nucleotide alignment from sequences obtained from Brazilian non-human primates and sequences isolated from humans: Sequences TA278 (AB17610), JA1 (AF122916), T3PB (AF247138), TGP96 (AB041962), SANBAN (AB025946), TLMVCDB203 (AB026929), TLMV-CDB231 (AB026930), TUS01 (AB017613), TJN01 (AB028668) are from human sequences MfTTV3 (AB041958), MfTTV9 (AB041959), PtTTV6 (AB041957), Pt-TTV8II (AB041963), SoTTV2 (AB041960), AtTTV3 (AB041961) are from non-human primates, and sequence is from CAV/U65414 (U65414) chicken. Identification of isolates characterized in this study arepresented in bold. Dots indicate nucleotide identities, whereas dashes indicate gaps. 
Regarding the 2 samples positives for the ORF-2 region, the DNA TTV was detected in sera from $1(1.3 \%)$ out of 75 Cebus apella and in whole blood of $1(4 \%)$ of 25 Callithrix jaccus, of which $1(50 \%)$ was a female and the other $(50 \%)$ a male, all adults (Table I).

Phylogenetic analysis of the UTR-A region (Fig. 1) of the 11 serum samples, showed that among these TTV sequences obtained from non-human primates analysed in this study, eight of them clustered with one sequence of the cottontop tamarin (Saguinus oedipus) (So-TTV2) and with one sequence of the Aotes trivirgatus (At-TTV3), from the primates Park in Japan. The other three sequences showed similarity with a human TLMV sequence (Torque Teno Minivirus).
The two sequences amplified by ORF-2 region clustered with the human TTV strain TA278.

Gallus gallus domesticus. No positive PCR was obtained from 117 plasm samples obtained from domestic chicken (Gallus gallus domesticus) white, and brown leghorn lineages and also leghorn var (chicken from poultry farm) by the nested-PCR for the UTR-A, and a positive samples was detected in a female adult white leghorn by the ORF-2 PCR. Phylogenetic analysis revealed that the amplified sequence did not differ from strains isolated in human or non-human primates. (Fig. 2).

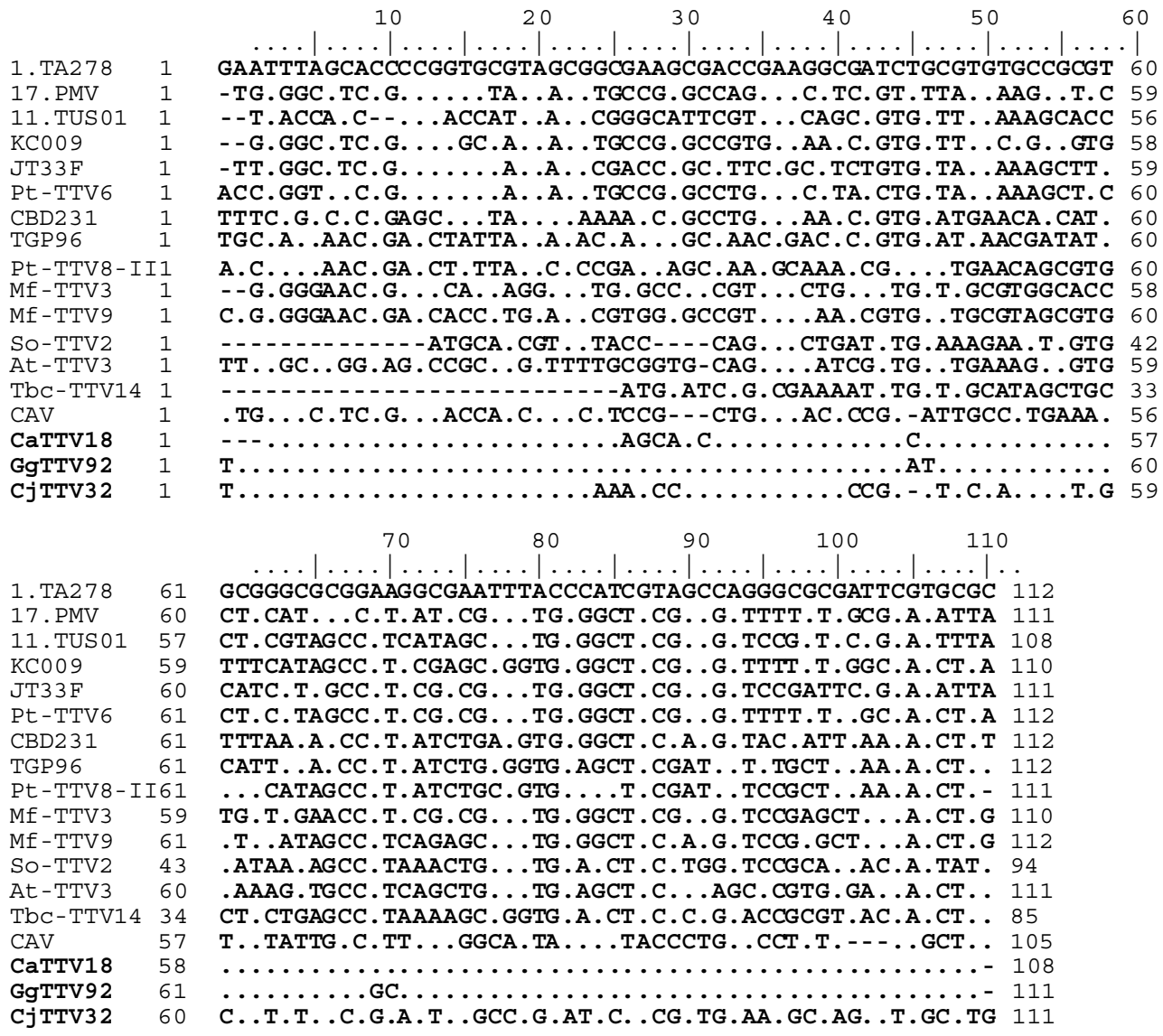

Fig. 2- Comparison between TTV-ORF-2 nucleotide sequences obtained from Brazilian non-human primates and sequences isolated from humans: TA278 (AB17610), PMV (AF261761), TUSO1 (AB017613), KC009-YONBAN (AB028668), JT33F (AB064606), TLMV-CDB231 (AB026930), TGP96 (AB041962) non-human primates: PtTTV6 (AB041957), Pt-TTV8II (AB041963), MfTTV3 (AB041958), MfTTV9 (AB041959), SoTTV2 (AB041960), AtTTV3 (AB041961), tupaia: Tbc-TTV14 (AB057358), swine: Sd-TTV31 (AB076001) and from chickens: CAV (M55918). Isolates determined in this study are presented in bold. 


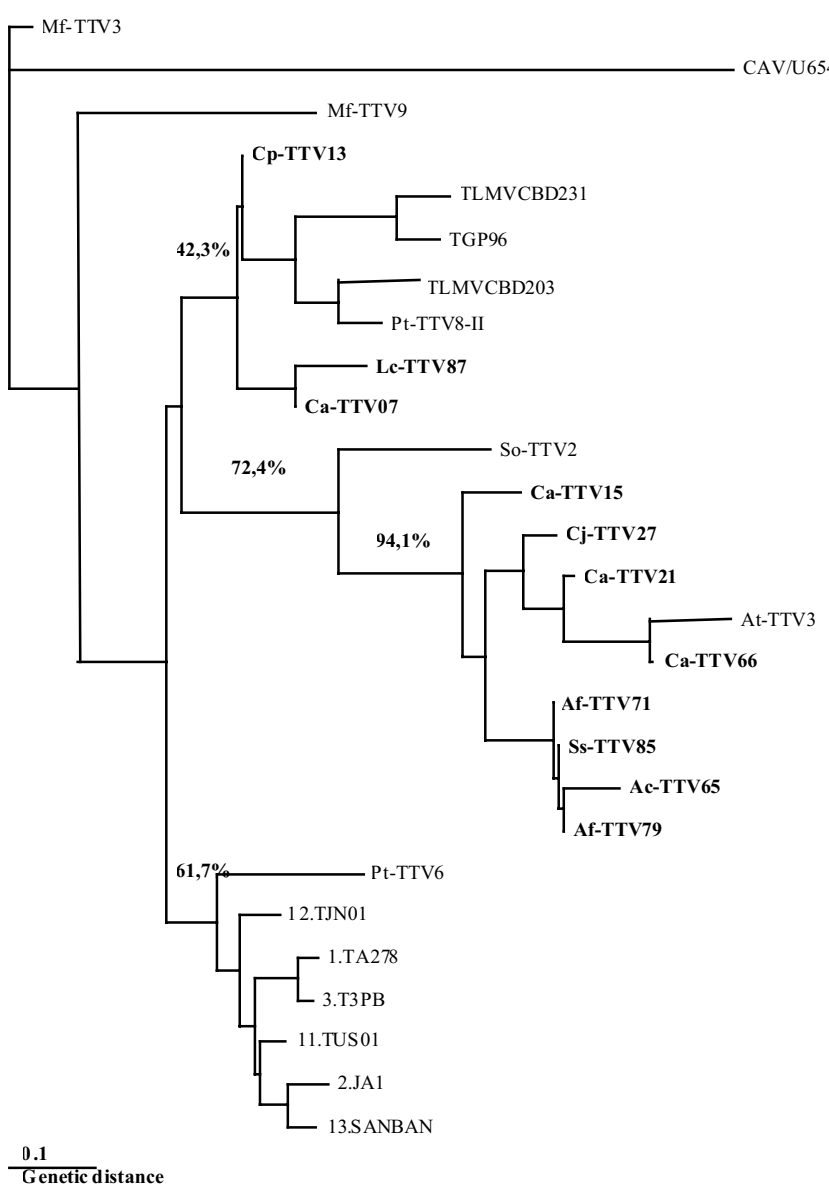

Fig. 3. Phylogenetic relationship between TTV UTR-A nucleotide sequences obtained from Brazilian non-human primates and sequences isolated from humans, non-humans primates and chickens. The phylogenetic trees were constructed by the neighbourjoining method (Saitou \& Nei, 1987). Isolates determined in this study are presented in bold. The database-derived isolates and their accession numbers is given in the legend to Fig. 1.

\section{DISCUSSION}

Two distinct methods are widely used for the detection of TTV DNA: the N22 PCR, using primers based on the sequence of the coding region and the UTR PCR, using primers based on the sequence of the conserved UTR (Okamoto et al., 2000a,b). The UTR PCR can detect essentially all genotypes, and it has been called "universal" or "general" PCR for the detection of TTV (Okamoto \& Mayumi, 2001).

In our study, approximately 160 samples, of which 90 of serum and 70 of whole blood obtained from different nonhuman primate species from Brazil were tested by the nested PCR for the UTR-A region to detect TTV DNA. This was detected in 11 out of 90 non-human-primates of this study $(6.9 \%)$.

Similarly, one study found $23.5 \%$ of TTV DNA in serum of Saguinus labiatus and in $20 \%$ in Aotus trivirgatus, whereas other studies did not detect TTV DNA in any other serum of new world primates (Leary et al.; Verschoor et al.; Romeo et al.; Barnett et al.; Pujol et al.). Additionally, other study (Okamoto et al. 2000a) obtained 100\% of TTV DNA positivity in 4 Saguinus labiatus serum's, in $83 \%$ out of 6 Saguinus aedipus, and $100 \%$ of 5 Aotes trivirgatus samples. On the other hand, some authors obtained positive from 14 to $100 \%$ investigate among samples from old world primates, (Abe et al., 2000; Romeo et al.; Thom et al., 2003; Pujol et al.; Barnett et al.; Verschoor et al.; Okamoto et al., 2000a; Leary et al.; Noppornpanth et al.).

In our study the most prevalent non-human primate specie was the Cebus apella, which is the specie with the wildly geographical distribution in the Americas (Auricchio, 1995). However, another study did not detect TTV DNA in any of 9 samples of Cebus apella (Abe et al. 2000).

Of the 11 positive samples detected in our study, 5 $(45.5 \%)$ were from female monkeys and 6 from males $(54.5 \%)$, confirming that there is probably no bias of TTV infection among males and females, as showed by other study that detected $48.3 \%$ (29 of 60) TTV infection among male chimpanzee and $49.2 \%$ among females (31 of 63) (Verschoor et al.).

It is interesting to note that one study observed a higher incidence of TTV infection among adult animals (30 of 46, $65.2 \%$ ) as compared to new born and juvenile chimpanzees (8 of 37, 21.6\%) (Verschoor et al.). Therefore, older animals may play an important role in the transmission pattern in a monkey breeding place and further studies should be conducted to specifically address the causes for these findings.

Interestingly, 8 out of 11 samples characterized in our study clustered in the phylogenetic analysis with two previously described strains isolated from non-human primates (Okamoto et al. 2000a), thus suggesting that, although there are some strains from non-human primates similar to strains found in humans (Leary et al.), some strains may be specific for non-human primates. It is important to point out that usually TTV sequences isolated from chimpanzees will be distinct from strains isolated in humans. (Abe et al., 2000; Romeo et al.; Barnett et al.).

The results of our research showed that three sequences had similarity with a human TLMV sequences. Indeed, several studies showed that the infection with both TTV and 


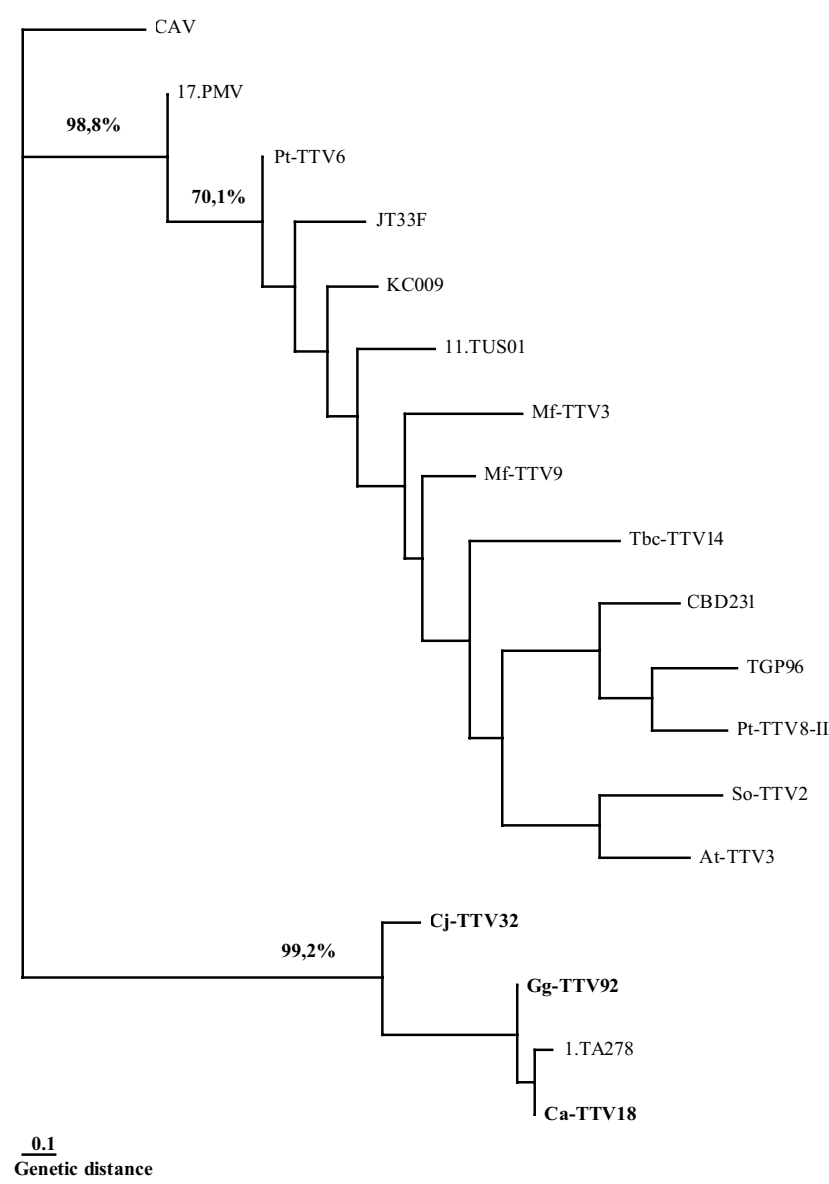

Fig. 4. Phylogenetic relationship between TTV ORF2 nucleotide sequences obtained from Brazilian non-human primates and from chicken (Gallus gallus domesticus) and sequences isolated from humans, non-humans primates, tupaia, swine and chicken. The phylogenetic trees were constructed by the neighbour-joining method (Saitou \& Nei, 1987). Bootstraps above 700 are presented. Isolates determined in this study are presented in bold. The databasederived isolates and their accession numbers is given in the legend to Fig. 2.

TLMV have been detected in a range of non-human primates (Verschoor et al.; Abe et al., 2000; Okamoto et al., 2000ab; Romeo et al.; Thom et al.). There are some evidences that corroborate frequent infection by TTV and TLMV related virus in a wide range of old world apes (chimpanzees, gorillas, orangutans, gibbons, mangabeys, drills and mandrills), raising the hypothesis that the TTV-like viruses co-evolved with their hosts over the period of primate speciation (Thom et al.).

Considering that the inespecifity of primers which amplify the UTR, and that for some animals species the UTR region is located close to the ORF2 region, two samples (one of Cebus apella and one of Callithrix jacchus) were amplified only with ORF primers. When comparing the 2 sequences from the ORF2 region samples a clustering was observed with the
TA278 human prototype sequence, which to our knowledge, is a unique finding in the literature. This sort of similarity was found among strains isolated from one chimpanzee (Pt-TTV6) and the TA278 from humans, by the phylogenetic tree constructed on the amino acid sequences of ORF2.

When chickens' samples were analyzed (Gallus gallus domesticus), it was observed that none among the 117 plasm samples studied in our researches were amplified by the nestedPCR UTR-A reaction. These data are in accordance with the findings of other study Thom et al. (2003) which observed that all the 29 chicken samples, as well as the 20 samples from cows, 20 from sheep and 20 from goats, were PCR negative.

On the other hand, it was observed in one chicken sample that the amplification of the ORF2 region was obtained.

In our study, the sequence of chicken clustered with the prototype TTV human TA 278, which is in accordance with other study (Leary et al.) that found similarity between sequences amplified in humans and other animals, including birds, thus confirming TTV is able to infect a wide range of mammals as well as avian species.

Our date indicate that TTV is present in Brazilian new world monkeys in captivity, although in low prevalence, and these viruses can be hardly ever encountered in chickens. Considering that there is a great deal of contact between the Brazilian population and the animal life and captivity, virus might be transmitted through feeding processes or by the treatment applied to animals.

The enteric transmission demonstrated experimentally in non-human primates (Luo \& Zhang 2001), indicates that the fecal-oral route, associate to sanitaryand also the precarious conditions of hygiene can be of importance in the dissemination of the TTV. Additional explanations can be considered regarding TTV presence in the animals used in this study. These animals when submitted to stress situations such as changes of temperatures or feeding, transport, intercourse, etc. could develop the disease resulting in great threat mainly to those species included in the official list of the Brazilian fauna at risk of extinction, such as the golden faced lion tamarin (Leontopithecus crysomelas).

We acknowledge that the small sample size and the bias of the analysis of animals in captivity preclude more conclusive considerations. However, we believe that the results of our study can be of importance for the design of future studies to address questions related to the dissemination cycle and pathogenicity of TTV in animal species and humans. 
CATROXO, M. H. B.; NISHIYA, A.; SABINO, E.; TEIXEIRA, P. S.; PETRELLA, S.; MILANELO, L.; VIEIRA, J. C. F. \& DIAZ, R. S. Torque Teno virus (TTV) es prevalente en primates no humanos brasileños y pollos (Gallus gallus domesticus). Int. J. Morphol., 26 (2):363-372, 2008.

RESUMEN: Torque Teno virus (TTV) es una agente infeccioso de distribución mundial, aislado por primera vez como el agente de una hepatitis aguda posterior a la transfusión de un paciente en Japón. Se ha clasificado en un nuevo género flotante llamado Anellovirus. Recientes estudios han demostrado que TTV también puede ser identificado en el suero de especímenes obtenidos desde granjas de animales domésticos y desde primates no humanos. Para entender mejor la relación entre la TTV y sus huéspedes, fue realizado un estudio para detectar el virus en el suero y la sangre de primates no humanos brasileños y en el plasma de pollos mediante la aplicación de la técnica PCR-UTR-A, seguida de una secuencia genómica y análisis filogenético. Por medio de PCR-UTR-anidado, el ADN de TTV fue detectado en sueros de 4 de 75 (5,3\%)Cebus apella, 2 de 5 (40\%) Alouata fusca, 1 de 5 (20\%) de Alouata caraya, 1 de 19 (5,2\%) de Callithrix penicilata, 1 de 25 (4\%) Callithrix jacchus, 1 de 5 (20\%) de Saimiri sciureus y 1 de 4 (25\%) de Leontopithecus chrysomelas. El análisis filogenético reveló secuencias detectadas en 8 muestras agrupadas con TTV secuencias So-TTV2 (Sagüínus oedipus) y AtTTV3 (Aotes Trivirgatus). Tres secuencias mostraron similitud con el Torque Teno Minivirus humano (TLMV). Fue detectado TTV ORF2 ADN en una muestra de suero y una muestra de sangre de primates no-humanos y en una muestra de plasma de pollo. El análisis filogenético reveló que las secuencias amplificadas por la región ORF2 no muestran ninguna diferencia entre humanos, primates no humanos y pollos. Este es el primer informe de nuevos TTV en primates-no humanos brasileños y en pollos.

PAlabRas Clave: Torque Teno virus; Torque Teno Minivirus; Primates no humanos; Región no traducida; Secuenciación de nucleótidos.

\section{REFERENCES}

Abe, K.; Inami, T.; Asano, K.; Miyoshi, C.; Masaki, N.; Hayashi, S.; Ishikawa, K. I.; Takebe, Y.; Win, K. M.; El-Zayadi, A. R.; Han, K-H. \& Zhan, D.Y.; TT virus infection is widespread in the general populations from different geographic regions. J. Clin. Microbiol., 37:2703-5, 1999.

Abe, K.; Inami, T.; Ishikawa, K.; Nakamura, S. \& Goto, S. TT virus infection in nonhuman primates and characterization of the viral genome: identification of Simian TT virus isolates. J. Virol., 74(3):1549-53, 2000.

Al-Moslih, M.I.; Perkins, H. \& Hu, Y.W. Genetic relationship of Torque Teno virus (TTV) between humans and camels in United Arab. Emirates (UAE). J. Med. Virol., 79:188-91, 2007.

Auricchio, P. Primatas do Brasil. Terra Brasilis Editora Ltda. São Paulo, Brasil, 1995. 168p.

Barnett, O. E.; Worobey, M.; Homes, E. C. \& Cooper, A. Detection of TT virus among chimpanzees in the wild using a noninvasive technique. J. Wildl. Dis., 40:230-7, 2004.

Biagini, P.; Todd, D. \& Bendinelli, M. Anellovirus. In Virus Taxonomy. Eighth Report of the International Committee on Taxonomy of Viruses, pp. 335-41. Edited. by C. M. Fauquet, M. A. Mayo, J. Maniloff, U. Desselberger \& L. A. Ball. London, Academic Press, 2005.

Bigarré, L.; Beven, V.; Boissédon, C.; Grasland, B. ; Rose, N. ; Biagini, P. \& Jestin, A. Pig anelloviruses are highly prevalent in swine herds in France. J. Gen. Virol., 86:631-5, 2005.

Cong, M.; Nichols, B.; Dou, X.; Spelbring, J.E.; Krawczynski, K.; Fields, H. A. \& Khudyakov, Y. E. Related TT viruses in chimpanzees. Virology., 274:343-55, 2000.

Devalle, S. \& Niel, C. Distribution of TT virus genomic groups 1-5 in Brazilian blood donors, HBV carriers, and HIV-1 infected patients. J. Med. Virol., 72:166-73, 2004.

Diniz-Mendes, L.; Devale, S. \& Niel, C. Genomic characterization of a Brazilian TT virus isolate closely related to SEN Virus-F. Mem. Inst. Oswaldo Cruz., 99:301-6, 2004.

Erker, J. C.; Leary, T. P.; Desai, S. M.; Chalmers, M. L. \& Mushahwar, I. K. Analysis of TT virus full-length genomic sequences. J. Gen.Virol., 80:1743-50, 1999.

Felsenstein, J. PHILIP, version 3.5. Dept. of Genetics, University of Washington, Seattle, USA, 1993. (Distributed by the author at http://evolution.genetics.washington.edu/ phylip.html).

Goto, K.; Sugiyama, Ando, T.; Mizutani, F.; Terabe, K.; Tanaka, K.; Nishiyama, M. \& Wada, Y. Detection rates of TT virus DNA in serum of umbilical cord blood, breast milk and saliva. Tohoku. J. Exp. Med., 191(4):203-7, 2000.

Hallett, R. L.; Clewley, J. P.; Bobet, F.; McKiernan, P. J. \& Teo, C. G. Characterization fo a highly divergent TT virus genome. J. Gen. Virol., 81:2273-9, 2000. 
Hijikata, M.; Takahashi, K. \& Mishiro, S. Complete circular DNA genome of a TT virus variant (isolate name SANBAN) and 44 partial ORF2 sequences implicating a great degree of diversity beyond genotypes. Virology, 260:17-22, 1999.

Inami, T.; Obara, T.; Moriyama, M.; Arakawa, Y. \& Abe, K. Fulllenght nucleotide sequence of a simian TT virus isolate obtained from a chimpanzee: evidence for a new TT viruslike species. Virology, 277:330-5, 2000.

Itoh, J.; Takahashi, M.; Fukuda, M.; Shibayama, T.; Ishikawa, T.; Tsuda, F.; Tanaka, T.; Nishizawa, T. \& Okamoto, H. Visualization of TT virus particles recovered from the sera and feces of infected humans. Bioch. Bioph. Res. Comm., 279:718-24, 2000.

Khudyakov, Y. E.; Cong, M. E.; Nichols, B.; Reed, D.; Dou, X. G.; Viazov, S. O.; Chang, J.; Fried, M.W.; Roggendorf, M.; Fields, H.A. Sequence heterogeneity of TT virus and closely related viruses. J.Virol., 74(7):2990-3000, 2000.

Leary, T. P.; Erker, J. C.; Chalmers, M. L.; Desai, S. M. \& Mushahwar, I. K. Improved detection systems for TT virus reveal high prevalence in humans, non-humans primates and farm animals. J. Gen. Virol., 80:2115-20, 1999.

Luo, K. \& Zhang, L. Enteric transmission of transfusiontransmitted virus. Chin. Med. J., 114:1201-4, 2001.

Martelli, F.; Caprioli, A.; Di Bartolo, I.; Cibin, V.; Pezzotti, G. Ruggeri, F. M. \& Ostanello, F. Detection of swine Torque teno virus in Italian pig herds. J. Vet. Med., B53:234-8, 2006.

Martinez, L.; Kekarainen, T.; Sibila, M.; Ruiz-Fons, F.; Vidal, D. \& Segales, J. Torque teno virus (TTV) is highly prevalent in the European wild boar (Sus scrofa). Vet. Microbiol., 118(34):223-9, 2006.

Mc Keown, N. E.; Fenaux, M.; Halbur, P. G. \& Meng, X. J. Molecular characterization of porcine TT virus, and orphan virus, in pigs from six different countries. Vet. Microbiol., 104:113-7, 2004.

Miyata, H.; Hsunoda, H.; Kazi, A.; Yamada, A.; Khan, M.A.; Muakami, J.; Kamahora, T.; Shiraki, K. \& Hino, S. Identification of a novel GC-rich 113 nucleotide region to complete the circular single-stranded DNA genome of TT virus, the first human circovirus. J. Virol., 73:3582-6, 1999.

Mushahwar, I. K.; Erker, J. C.; Murchoff, A. S.; Leary, T. P.; Simons, J. N.; Birkenmeyer, L. G.; Chalmers, M. L.; PilotMatias, T. J. \& Desai, S.M. Molecular and biophysical characterization of TT virus: evidence for a new virus family infecting humans. Proc. Natl. Acad. Sci., USA. 96:3177-82, 1999.
Niel, C. \& Lampe, E. High detection rates of TTV-like mini virus sequences in sera from Brazilian blood donors. J. Med. Virol., 65(1):199-205, 2001.

Niel, C.; Diniz-Mendes, L. \& Devalle, S. Rolling-circle amplification of Torque teno virus (TTV) complete genomes from human and swine sera and identification of a novel swine TTV genogroup. J. Gen. Virol., 86:1343-7, 2005.

Nishizawa, T.; Okamoto, H. Konishi, K.; Yoshizawa, H.; Miyakawa, Y. Mayumi, M. A novel DNA virus (TTV) associated with elevated transaminase levels in posttransfusion hepatitis of unknown etiology. Biochem. Biophys. Res. Commun., 241:92-7, 1997.

Noppornpanth, S.; Chingai, T.; Ratanakorn, P. \& Poovorawan, Y. TT virus infection in gibbons. J. Vet. Med. Sci., 63:663-6, 2001.

Okamoto, H.; Akahane, Y.; Ukita, M.; Fukuda, M.; Tsuda, F.; Miyakawa, Y. \& Mayumi, M. Fecal excretion of a nonenveloped DNA virus (TTV) associated with posttransfusion non A-G hepatitis. J. Med.Virol., 56:128-32, 1998b.

Okamoto, H.; Fukuda, M; Tawara, A.; Nishizawa, T.; Itoh, Y.; Ayasaka, I.; Tsuda, F.; Tanaka, T.; Miyakawa, Y. \& Mayumi, M. Species-specific TT virus and cross-species infection in nonhuman primates. J. Virol., 74(3):1132-9, 2000a.

Okamoto, H.; Kato, N.; Lizuka, H.; Tsuda, F.; Miyakawa, Y. \& Mayumi, M. Distinct genotypes of a nonenveloped DNA virus associated with posttransfusionnon-A to G hepatitis (TT virus) in plasma and peripheral blood mononuclear cells. $J$. Med. Virol., 57:252-8, 1999a.

Okamoto, H. \& Mayumi, M. TT virus: virological and genomic characteristics and disease associations. J. Gastroenterol., 36:519-29, 2001.

Okamoto, H.; Nishizawa, T.; Kato, N.; Ukita, M.; Ikeda, H.; Lizuka, H.; Miyakawa, Y. \& Mayumi, M. Molecular cloning and characterization of a novel DNA virus (TTV) associated with postransfusion hepatitis of unknown etiology. Hepatol. Res., 10:1-16, 1998a.

Okamoto, H.; Nishizawa, T.; Takahashi, M.; Asabe, S.; Tsuda, F. \& Yoshikawa, A. Heterogeneous distribution of TT virus of distinct genotypes in multiple tissues from infected humans. Virology, 288:358-68, 2001a.

Okamoto, H.; Nishizawa, T.; Takahashi, M.; Tawara, A.; Peng, Y.; Kishimoto, J. \& Wang, Y. Genomic and evolutionary characterization of TT virus (TTV) in Tupaias and comparison with species-specific TTVs in humans and nonhuman primates. J. Gen. Virol., 82:2041-50, 2001 b. 
Okamoto, H.; Nishizawa, T.; Tawara, A.; Peng, Y.;Takahashi, M.; Kishimoto, J.; Tanaka, T.; Miyakawa, Y. \& Mayumi, M. Species-specific TT viruses in humans and nonhuman primates and their phylogenetic relatedness. Virology, 277(2):368-78, $2000 \mathrm{~b}$.

Okamoto, H.; Nishizawa; Ukita, M.; Takahashi, M.; Fukuda, M.; Lizuka, H.; Miyakawa, Y. \& Mayumi, M. The entire nucleotide sequence of a TT virus isolate from the United States (TUS 01): comparison with reported isolates and phylogenetic analysis. Virology, 259:437-48, 1999b.

Okamoto, H.;Takahashi, M.; Nishizawa, T.; Tawara, A.; Fukai, K.; Muramatsu, U.; Naito, Y. \& Yoshikawa, A. Genomic characterization of TT viruses (TTVs) in pigs, cats and dogs and their relatedness with species-specific TTV in primates and tupaias. J. Gen. Virol., 83:1291-7, 2002.

Okamoto, H.; Takahashi, M.; Nishizawa, T.; Ukita, M.; Fukuda, M.; Tsuda, F.; Miyakawa, Y. \& Mayumi, M. Marked genomic heterogeneity and frequent mixed infection of TT virus demonstrated by PCR with primers from coding and noncoding regions. Virology. 259:428-36, 1999c.

Osiowy, C. \& Sauder, C. Detection of TT virus in human hair and skin. Hepatol. Res., 16:155-62, 2000.

Peng, Y, H.; Nishizawa, T.; Takahashi, M.; Ishikawa, t.; Yoshikawa, A. \& Okamoto, h. Analysis fo the entire genomes of thirteen TT virus variants classifiable into the fourth and fifth genetic groups, isolated from viremic infants. Arch. Virol., 147:21-41, 2002.

Prescott, L. E. \& Simmonds, P. Global distribution of transfusiontransmitted virus. New Engl. J.Med., 339(11):776-7, 1998.

Pujol, F. H.; Mejías, E.; Loreiro, C. L.; Ludert, J. E.; Liprandi, F. \& Pernalete, J.M. Infection with transfusion-transmitted virus (TTV) in humans and other primates in Venezuela. Ann. Trop. Med. Parasitol., 99:173-80, 2005.

Roderic, D.M.Treeview. Glasgow, Scotland: University of Glasgow, (Distributed by the author at http:// taxonomy.zoology.gla.ac.uk/rod/treeview.htm)., 2001.

Romeo, R.; Hegerich, P.; Emerson, S.U.; Colombo, M.; Purcell, R. H. \& Bukh, J. High prevalence of TT virus (TTV) in naive chimpanzees and in hepatitis $\mathrm{C}$ virus-infected humans: frequent mixed infections and identification of new TTV genotypes in chimpanzees. J. Gen. Virol., 81:1001-7, 2000.

Saback, F.L.; Gomes, S. A. S.; Paula, V. S.; Da Silva, R. R. S.; Lewis-Ximenez, L. L. \& Niel, C. Age specific prevalence and transmission of TT virus. J. Med. Virol., 59:318-22, 1999.
Saitou, N. \& Nei, M. The neighbor-joining method: a new method for reconstructing phylogenetic trees. Mol. Biol. Evol., 4:406-25, 1997.

Takahashi, K.; Hijikata, M.; Samokhvalov, E.I.; Mishiro, S. Full or near full lenght nucleotide sequences of TT virus variants (types SANBAN and YONBAN) and TT virus-like mini virus. Intervirology, 43(2):119-23, 2000.

Takahashi, K.; Iwasa, Y.; Hijikata, M. \& Mishiro, S. Identification of a new human DNA virus (TTV-like mini virus, TLMV) intermediately related to TT virus and chicken anemia virus. Arch.Virol., 145:979-93, 2000.

Tawara, A.; Akahane, Y.; Takahashi, M.; Nishizawa, T.; Ishikawa, T. \& Okamoto, H. Transmission of human TT virus of genotype 1a to chimpanzees with fecal supernatant or serum from patients with acute TTV infection. Biochem. Biophys. Res .Commun., 278(2):470-6, 2000.

Thom, K.; Morrison, C.; Lewis, J. C. M. \& Simmonds, P. Distribution of TT virus (TTV), TTV-like minivirus, and related viruses in humans and nonhuman primates. Virology, 306:324-33, 2003.

Ukita, M.; Okamoto, H.; Nishizawa, T.; Tawara, A.; Takahashi, M.; Lizuka, H.; Miyakawa, Y. \& Mayumi, M. The entire nucleotide sequences of two distinct TT virus (TTV) isolates (TJN01 and TJN02) remotely related to the original TTV isolates. Arch. Virol., 145:1543-59, 2000.

Verschoor, E. J.; Langenhuijzen, S. \& Heeney, J. L. TT viruses (TTV) of non-human primates and their relationship to the human TTV genotypes. J. Gen.Virol., 80:2491-9, 1999.

Yokoyama, H.; Yassuda, J.; Okamoto, H. \& Iwakura, Y. Pathological changes of renal epithelial cells in mice transgenic for the TT virus ORF1 gene. J.Gen.Virol., 83(1):141-50, 2002.

Correspondence to:

Prof. Dr. Márcia Catroxo

Electron Microscopy Laboratory

Biological Institute of São Paulo

Avenida Conselheiro Rodrigues Alves, 1252

CEP: 04014-002

Vila Mariana, São Paulo, SP,

BRAZIL

Email: catroxo@biologico.sp.gov.br 